\title{
Tyrosinase RT-PCR as a Supplement to Histology for Detecting Melanoma and Nevus Cells in Paraffin Sections of Sentinel Lymph Nodes
}

\author{
Hans Starz, M.D., Christian J. Haas, Ph.D., Gesa-Maria Schulz, M.D., Bernd-Rüdiger Balda, M.D. \\ Department of Dermatology and Allergology (HS, CJH, G-MS, B-RB), Laboratory of Molecular Pathology \\ (CJH), Klinikum Augsburg, Augsburg, Germany
}

The detection of tyrosinase mRNA in sentinel lymph nodes (SLNs) by reverse transcription polymerase chain reaction (RT-PCR) is a sensitive indicator for the presence of melanoma or nevus cells, but it does not enable a distinction between both. We have established an efficient method for extraction and reverse transcription of tyrosinase mRNA from paraffin sections that permits the close correlation of the RT-PCR results with (immuno)histologic findings in adjacent sections. One hundred fifty-three SLNs and 6 non-SLN specimens originating from 92 melanoma and 4 nonmelanoma patients were studied to test the reliability of this approach. The predictive value of positive RT-PCR results was 0.98 for the presence of melanoma or nevus cells; the corresponding negative predictive value was 0.83 . Furthermore, the detection rate of tyrosinase mRNA significantly correlated with tumor burden. Among the 33 melanoma-positive SLNs without nevus cells, positive RT-PCR results were obtained in all specimens with extended peripheral (S2) or deeply invasive (S3) micrometastases but in only $46 \%$ of the cases with few localized melanoma cells in the subcapsular zone (S1). Routine (immuno)histologic evaluation alone had missed microclusters of melanoma cells in one SLN and small nevus cell aggregates in six other SLNs. They were detected only during microscopic reexamination caused by a positive RT-PCR result. We conclude that histology and immunohistochemistry remain the indispensable gold standard for the identification of melanoma and nevus cells in SLNs. Additional molecular analyses using adjacent paraffin sections may further

\footnotetext{
Copyright (C) 2003 by The United States and Canadian Academy of Pathology, Inc.

VOL. 16, NO. 9, P. 920, 2003 Printed in the U.S.A.

Date of acceptance: May 29, 2003.

H.S. and C.J.H. contributed equally to this publication.

Address reprint requests to: Hans Starz, M.D., Department of Dermatol ogy and Allergology, Klinikum Augsburg, Stenglinstrasse 2, D-86156 Augs burg, Germany; fax: +49-821-400-3336; e-mail: hstarz@web.de.

DOI: $10.1097 / 01 . M P .0000086074 .55963 .24$
}

improve the diagnostic accuracy by sensitizing and guiding the microscopist's attention.

KEY WORDS: Melanoma, Metastasis, Nevocyte, Sentinel lymph node, Tyrosinase RT-PCR.

Mod Pathol 2003;16(9):920-929

Ten years ago, Morton et al. (1) published a new minimally invasive diagnostic method for the early detection of clinically inapparent regional lymph node metastases in high-risk melanoma patients. It protects those $20 \%$ of patients with micrometastatic involvement from the potentially dangerous delay of nodal surgery, whereas the other $80 \%$ without metastases can be spared from unnecessary radical elective lymph node dissections. Preoperative lymphoscintigraphy and "lymphatic mapping" using vital blue dye permits the location and selective removal of a single or a few lymph nodes. These sentinel lymph nodes (SLNs) represent the first potential extracutaneous targets of lymphatic metastasis from a primary melanoma. Based on this concept, further technical advances led to an even less invasive and almost perfectly reliable method called gamma-probe guided sentinel lymphadenectomy (SLNE) (2-5). At present, this is the most sensitive and efficient tool for the early detection and removal of nodal metastases in melanoma patients (6).

The definite diagnosis or exclusion of melanoma micrometastases in SLNs is achieved by the histological and immunohistochemical evaluation of adequate series of paraffin sections. This standard procedure was defined with broad international agreement in the Augsburg Consensus (7). It formed the basis for the development of the recently published micromorphometric S classification for SLN micrometastases, which proved to be of high prognostic relevance in melanoma patients $(8,9)$. The sensitivity of this procedure depends on the experience and accuracy of the investigator as well as on the number and quality of sections ex- 
amined and stains applied. Therefore, some investigators tried to detect melanoma micrometastases by the identification of tyrosinase mRNA using the extremely sensitive RT-PCR technique (10-15). This could, however, not displace histology and immunohistochemistry from their diagnostic priority because of a fundamental disadvantage. Although tyrosinase mRNA appears to be highly specific for melanocytic cells, a positive RT-PCR result in the SLN is not diagnostic for a melanoma metastasis. Benign nevus cells may contain the same type of mRNA, and they are not negligibly rare in SLNs of melanoma patients (16-18). Thus, false-positive diagnoses can only be avoided by a histological reexamination of the RT-PCR-positive sample. For RNA analyses, however, unfixed tissue has traditionally been used, resulting in the consumption of usually half of the SLN for RNA extraction. This portion of the SLN was irreversibly lost for any direct correlation with histology. It is, however, a questionable practice to compare the RT-PCR results in one half of the SLN with the (immuno)histochemical findings in the other half. As both melanoma micrometastases and nevus cell aggregates may be confined to one of these two samples, the resulting sampling error severely compromises the sensitivity of both methods and, even more, their correlation with each other. Thus, a diagnostic useful application of RT-PCR without impairment of the histological SLN evaluation is only possible by using paraffin sections for RNA analysis (18).

\section{MATERIALS AND METHODS}

\section{Selection of Cases and Sequence of SLN Analysis}

One hundred fifty-three paraffin-embedded SLNs originating from 96 patients (92 of them with melanoma, 4 with other skin malignancies) were taken from the files of our department. The corresponding SLNEs have been performed between December 1996 and June 2002. Routine evaluation of all SLNs by histology and immunohistochemistry (see below) had been completed before the performance of PCR analysis. The histological findings were not available to the persons involved in the molecular analyses before the definite RT-PCR results had been obtained. Those SLNs that were tyrosinase RT-PCR positive but had been histomorphologically negative in the routine screening were submitted to a second meticulous microscopic evaluation for melanoma and nevus cells that might have been missed during first examination.

\section{Gamma Probe-Guided SLNE}

Technical details have been reported elsewhere $(4,19)$. They were in agreement with the interna-

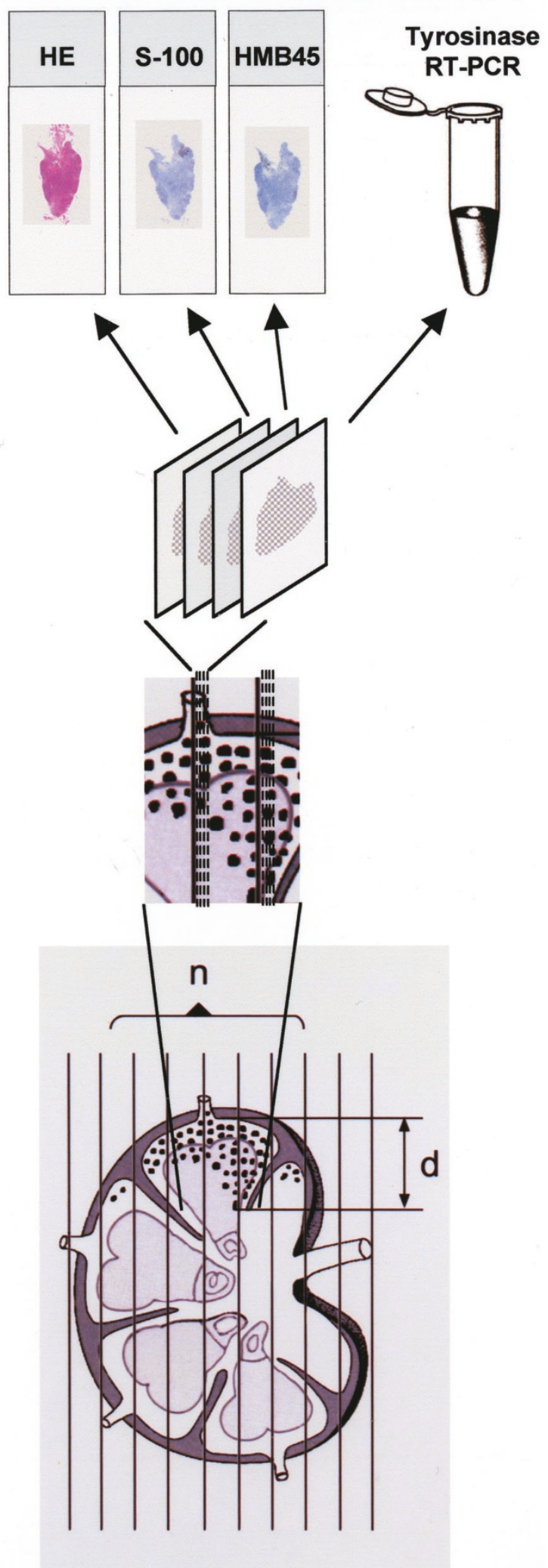

FIGURE 1. Schematic depiction of the method used for tissue sampling and analysis. After formalin fixation, the SLN is cut into slices of about $1 \mathrm{~mm}$ thickness. Each slice provides a series of adjacent semithin paraffin sections for conventional histology (HE = hematoxylin eosin stain), immunohistochemistry (with anti-S100 and the monoclonal antibody HMB45), and tyrosinase RT-PCR. $n$ means the number of SLN slices with microscopically identified melanoma cells, $d$ means the maximum distance of melanoma cells in the SLN to the interior margin of the lymph node capsule. 
tionally accepted standards as published in the Augsburg Consensus (7).

\section{Fixation and Processing of the SLNs}

Immediately after surgery, the SLNs were immersed in sufficient volumes of phosphatebuffered formalin (4.5\%, pH 7.0) for about 24 hours. After fixation, they were cut parallel to their longitudinal axis into 1-mm-thick slices (Fig. 1). The number of slices varied between 2 and 16, depending on the size of each lymph node. The slices were placed face-down on the bottom of fluidpermeable, flat plastic containers. After dehydration by increasing concentrations of ethanol and xylene, the tissue slices were finally embedded in melted paraffin (Histosec-Pastillen [without DMSO]; Merck, Darmstadt, Germany) at a temperature of $60^{\circ} \mathrm{C}$. Cooled down to room temperature, each container provided a paraffin block that usually contained several slices of one SLN. The initial trimming of the paraffin blocks was thoroughly carried out in such a way that loss of tissue was minimized. Then four or five sections were cut from each block with a microtome in such a way that the profiles of each tissue slice were conserved in each section. Three of the sections, each $3 \mu \mathrm{m}$ thick, were mounted on glass slides for histology and immunohistochemistry. One or two further sections, each $6 \mu \mathrm{m}$ thick, were stored in sterilized plastic capsules for RNA analysis. They were pooled in such a way that each capsule finally contained at least one section from all the 1-mm slices of a defined SLN. To avoid RNA contamination, before cutting a new paraffin block, the microtome blade was replaced by a new one, and the microtome itself was always carefully cleaned with xylene. Altogether, an average of 24.6 and 10.8 sections per lymph node were cut for (immuno)histological and for molecular analysis, respectively.

\section{Histologic and Micromorphometric Evaluation}

One of the three sections per paraffin block mounted on microscope slides was stained with hematoxylin and eosin. The second section was immunolabeled with a polyclonal anti-S100 marker (DAKO, Glostrup, Denmark), and the third was immunolabeled with the monoclonal antibody HMB45 (Enzo, Farmingdale, NY). For detection, an avidin-biotin alkaline phosphatase staining system was used with fast red as chromogen (Bio-Genex, San Ramon, CA). All the sections were examined systematically for micrometastases using the $10 \times$ objective of the microscope. Special attention was paid to the lumina of afferent capsular lymph vessels and to the subcapsular sinuses where lymphogenous metastatic tumor cell microemboli enter the SLNs. In addition, nevus cell aggregates were recorded. These are typically localized between collagen fibers of the lymph node capsule or trabeculae, frequently in close association with afferent lymph vessels (Fig. 2A). Details about the identification of melanoma and nevus cells in SLNs and the appropriate use of immunohistochemistry have been published elsewhere (16-18).

Melanoma micrometastases were submitted to micromorphometric $S$ classification as reported recently $(8,9)$. It is based on two easily determined parameters: the number $(n)$ of SLN slices with (immuno)histologically identified melanoma cells and the maximum distance $(d)$ of tumor cells to the interior margin of the SLN capsule within the twodimensional setting of SLN sections (Fig. 1). Classification $\mathrm{S} 1$ is defined by $n \leq 2$ and $d \leq 1 \mathrm{~mm}$, equivalent to a focal peripheral metastasis (Fig. 2B); S2 by $n>2$ and $d \leq 1 \mathrm{~mm}$, marking a more extended or multifocal peripheral metastasis (Fig. 2C); and S3 by $d>1 \mathrm{~mm}$, standing for deeper invasive metastases (Fig. 2D). Classification S0 means absence of (immuno)histologically detectable melanoma cells in the respective SLNs.

\section{RNA Extraction and Tyrosinase RT-PCR Analysis}

The tissue sections for RNA extraction were deparaffinized in $1 \mathrm{~mL}$ of octane (20). After vigorous vortexing, $150 \mu \mathrm{L}$ of methanol were added. After vortexing again, the tissue was pelleted by centrifugation at $10,000 \times g$ for 2 minutes. The supernatant was removed, and the remaining tissue was vacuum dried for 20 minutes. Then the pellet was resuspended in $135 \mu \mathrm{L}$ of digestion buffer $(20 \mathrm{~mm}$ Tris- $\mathrm{HCl}, \mathrm{pH} 7.6,0.5 \% \mathrm{~N}$-laurylsarcosine, 1 м guanidine thiocyanate, and $25 \mathrm{~mm} 2$-mercaptoethanol) and $15 \mu \mathrm{L}$ of proteinase K (5 mg/mL; Sigma, St. Louis, MO) were added (21). After digestion overnight at $55^{\circ} \mathrm{C}$, RNA was extracted with $750 \mu \mathrm{L}$ of TRIzol (Life Technologies, Karlsruhe, Germany) according to the manufacturer's instructions. The final RNA pellet was dissolved in $50 \mu \mathrm{L}$ of DEPCtreated water.

Reverse transcription was performed in a $20-\mu \mathrm{L}$ reaction volume containing $11.6 \mu \mathrm{L}$ of RNA, $0.5 \mathrm{~mm}$ of each deoxynucleotide triphosphate, $0.2 \mu \mathrm{mol} / \mathrm{L}$ antisense primer for tyrosinase mRNA (22), 0.2 $\mu \mathrm{mol} / \mathrm{L}$ antisense primer for $\beta_{2}$-microglobulin mRNA (23), $4 \mu \mathrm{L}$ of first-strand buffer (Life Technologies), 10 mm DTT, 40 U RNaseOUT (Life Technologies), and $100 \mathrm{U}$ Superscript II RNase H Reverse Transcriptase (Life Technologies). Incubation was performed for 50 minutes at $42^{\circ} \mathrm{C}$, and finally the enzyme was inactivated by incubation at $70^{\circ} \mathrm{C}$ for 15 minutes.

For the specific amplification of tyrosinase cDNA, two consecutive PCRs were performed with the 


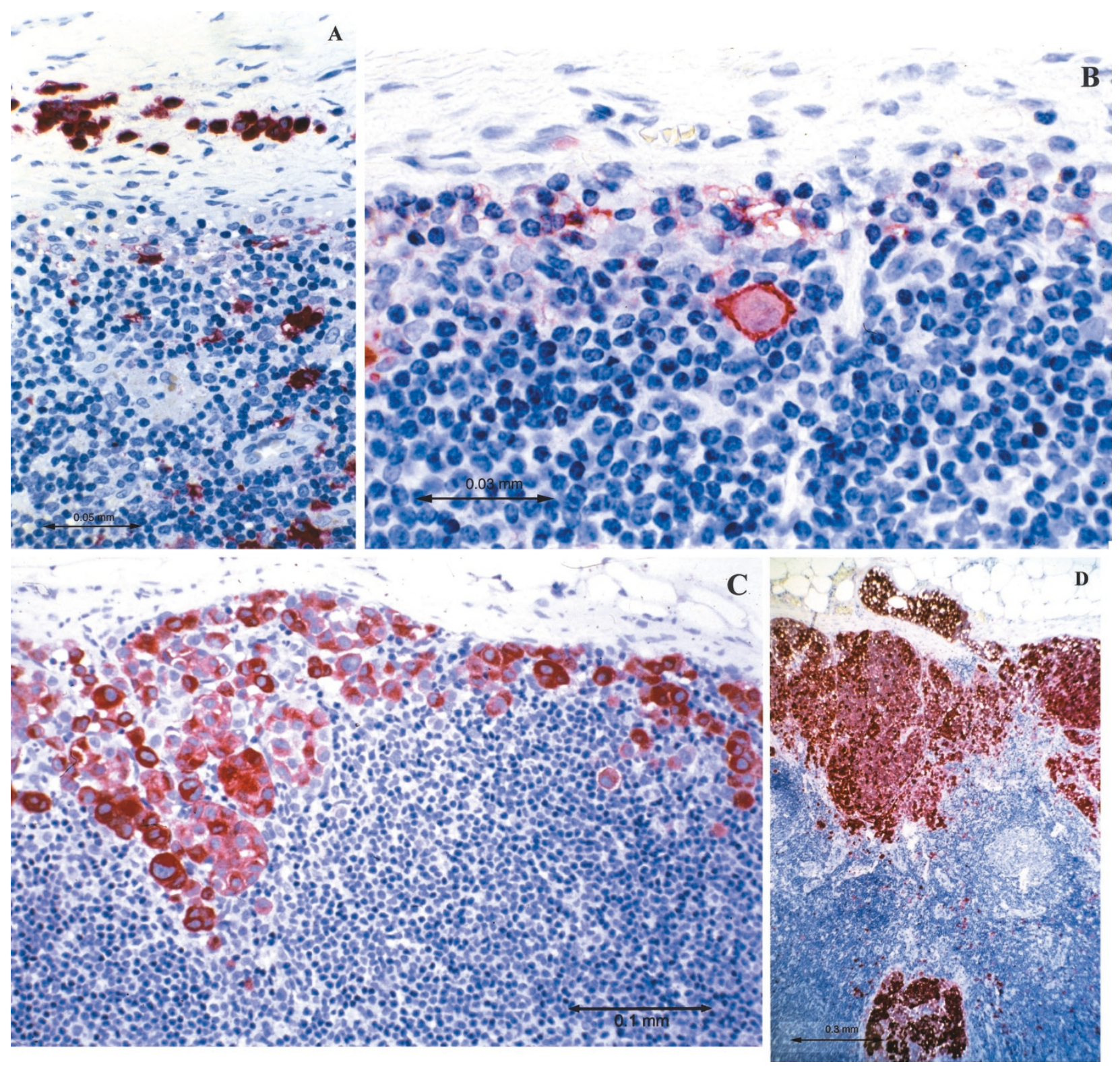

FIGURE 2. Examples of capsular nevus cells (A) and preferentially subcapsular melanoma cells (B-D) in SLNs. A single HMB45-positive melanoma cell equivalent to classification S1 is shown in B, a more extended peripheral S2 micrometastasis in $\mathbf{C}$, and an S3 metastasis in $\mathbf{D}$, characterized by a deep component. In addition, D visualizes an afferent capsular lymph vessel filled with clustered melanoma cells. Each of the sections in Panels $\mathbf{A}$, $\mathbf{C}$, and $\mathbf{D}$ is immunolabeled for the $\mathrm{S100}$ protein.

primer pairs HTYR1 and HTYR2 (outer primers) and HTYR3 and HTYR4 (inner primers), as described by Smith et al. (22).

In the first reaction, $1.0 \mu \mathrm{L}$ of cDNA was added to $24 \mu \mathrm{L}$ of the PCR reaction mixture containing 10 mu Tris- $\mathrm{HCl}$ (pH 8.3), $50 \mathrm{~mm} \mathrm{KCl,} 1.5 \mathrm{~mm} \mathrm{MgCl}_{2}, 0.2$ mM of each deoxynucleotide triphosphate (Amerham Pharmacia, Uppsala, Sweden), $0.8 \mu \mathrm{M}$ of each outer primer, and $0.025 \mathrm{U} / \mu \mathrm{L}$ AmpliTaq Gold (Applied Biosystems, Foster City, CA). The nested PCR was performed with the inner primer pair and with $0.5 \mu \mathrm{L}$ of the first amplification product to a total volume of $20 \mu \mathrm{L}$. PCR conditions for both reactions were the same: 10 minutes at $95^{\circ} \mathrm{C}$, followed by 45 cycles of 30 seconds of melting at $94^{\circ} \mathrm{C}, 30$ seconds of annealing at $56^{\circ} \mathrm{C}$, and 30 seconds extension at $72^{\circ} \mathrm{C}$. After the final cycle, another 8 minutes at $72^{\circ}$ $\mathrm{C}$ was added. The nested PCR resulted in a specific product of $207 \mathrm{bp}$.

As control for the quality of RNA extraction and cDNA synthesis, $\beta_{2}$-microglobulin mRNA was reverse transcribed in the same approach as for tyrosinase reverse transcription. The resulting cDNA was amplified in a separate PCR tube under the same conditions as the PCR with the outer primer set for tyrosinase amplification. The primers used were described by Oda et al. (23) and resulted in a 120 -bp segment of the $\beta_{2}$-microglobulin DNA. 
For evaluation, the PCR products were electrophoresed on a $4 \%$ agarose gel and stained with ethidium bromide (Fig. 3).

\section{Statistical Evaluation}

The documentation of all the relevant data and the statistical analyses were assisted by the computer program SPSS (version 10.0 for Windows, Chicago, IL).

The correlations between the tyrosinase RT-PCR results (positive versus negative) and the different (immuno)histologic findings (e.g., absence versus presence of melanoma or nevus cells, melanoma versus nevus versus melanoma + nevus cells, classification $\mathrm{S} 1$ versus $\mathrm{S} 2$ versus $\mathrm{S} 3$ ) were studied using contingency tables and the Spearman correlation.

\section{RESULTS}

Amplification of $\beta$-2-Microglobulin cDNA as Control for the Reliability of mRNA Extraction and Reverse Transcription

The success of the extraction procedure was monitored by reverse transcription of $\beta_{2}$ microglobulin mRNA and the following amplification of a specific 120-bp segment (23). The expected PCR product was obtained from all investigated samples.

\section{Correlation of RT-PCR Results with the} Histological Detection of Melanoma and/or Nevus Cells in the SLNs

Table 1 represents the contingency table between absence versus presence of melanoma or nevus
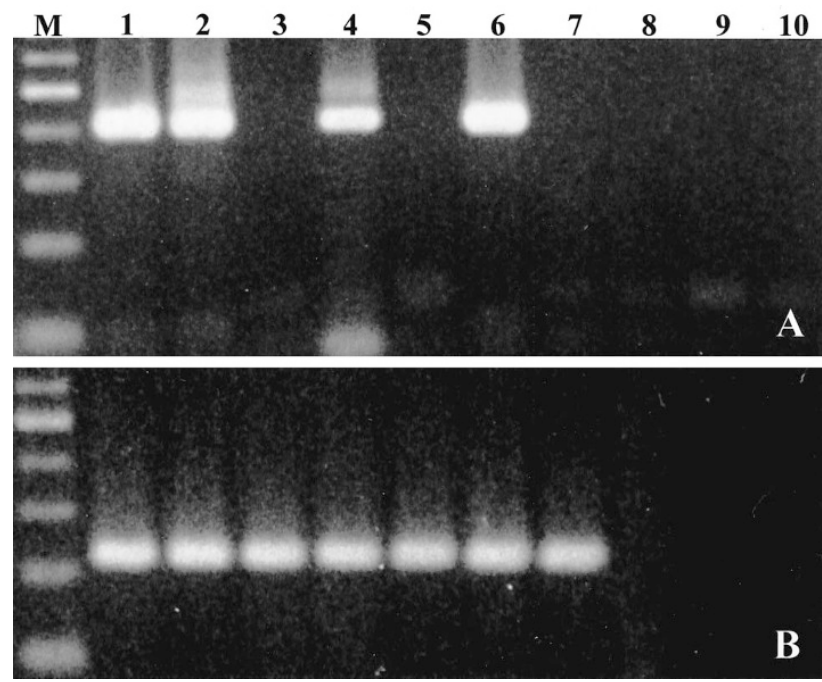

FIGURE 3. Tyrosinase and $\beta 2$ microglobulin RT-PCR products separated on an ethidium bromide-stained agarose gel. The 207-bp amplification product of nested PCR of tyrosinase (A) and the 120-bp PCR product of $\beta$-2-microglobulin cDNA (B) is shown. Lanes 1-6: cDNA from SLN of various patients; Lane 7: cDNA of negative control lymph node; Lane 8: RNA control; Lane 9: blank (RT control); Lane 10: blank (PCR control); M: 50-bp standard.
TABLE 1. Contingency between the (Immuno-) Histological Detectability of Melanoma or Nevus Cells and the Corresponding Tyrosinase RT-PCR Result in 159 Investigated Specimens

\begin{tabular}{lcc}
\hline \multirow{2}{*}{ Tyrosinase RT-PCR } & \multicolumn{2}{c}{ Melanoma or Nevus Cells } \\
\cline { 2 - 3 } & Present & Absent \\
\hline Positive & 43 & 1 \\
Negative & 20 & 95 \\
\hline
\end{tabular}

Spearman correlation, two-sided: $P=.000001$, correlation coefficient 0.735 .

cells (Criterion 1) and negative versus positive RTPCR results regarding tyrosinase mRNA (Criterion 2). It contains all of the 159 tissue samples tested. The corresponding Spearman correlation results in a correlation coefficient of 0.735 and a high level of significance $(P=.000001)$. Only one false-positive RT-PCR result was obtained among 96 histomorphologically negative samples, indicating a $99 \%$ specificity of the presented method in this pilot study for the identification of melanoma or nevus cells (Fig. 4). Conversely, tyrosinase RT-PCR was positive in 43 of the 63 cases with (immuno)histologically verified melanoma or nevus cells, equivalent to an overall sensitivity of $68 \%$. The predictive value of a positive RT-PCR result for the presence of melanoma or nevus cells in the lymph node was 0.98 , and the predictive value of a negative result for the absence of these cells was 0.83 .

Table 2 focuses on the mentioned 63 cases and distinguishes among SLNs with melanoma cells only, those with nevus cells only, and a third smaller group with both melanoma and nevus cells. Criterion 2 in this second contingency table is identical with Criterion 2 in the first one. The associated Spearman correlation is not significant $(P=.054$, correlation coefficient of 0.244 ), supplying clear ev-

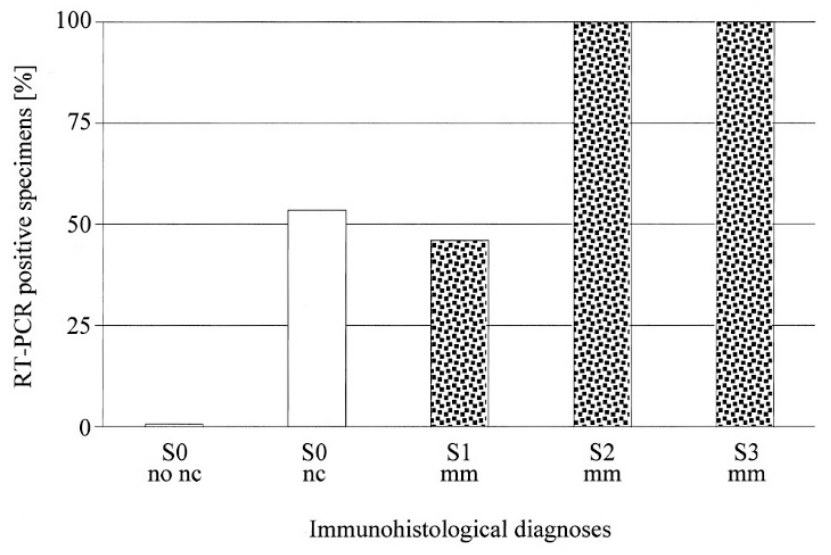

FIGURE 4. Percentages of positive tyrosinase RT-PCR results in relation to the respective (immuno)histological diagnoses from a total of 149 paraffin-embedded SLNs (see also Tables 1, 2, and 5). Four SLNs containing both melanoma and nevus cells were excluded from this diagram because their further differentiation into distinct $\mathrm{S}$ classifications would have created "collectives" encompassing only one or two specimens. $\mathrm{nc}=$ nevus cells, $\mathrm{mm}=$ melanoma metastasis. 
TABLE 2. Contingency between the Presence of Melanoma Cells versus Nevus Cells versus Both and the Related Tyrosinase RT-PCR Results in a Total of 63 SLN Specimens

\begin{tabular}{lccc}
\hline Tyrosinase RT-PCR & $\begin{array}{c}\text { Melanoma } \\
\text { Cells }\end{array}$ & $\begin{array}{c}\text { Nevus } \\
\text { Cells }\end{array}$ & $\begin{array}{c}\text { Melanoma }+ \\
\text { Nevus Cells }\end{array}$ \\
\hline Positive & 26 & 14 & 3 \\
Negative & 7 & 12 & 1 \\
\hline
\end{tabular}

Spearman correlation, two-sided: $P=.054$, correlation coefficient 0.244

idence that tyrosinase RT-PCR is not appropriate for differentiating between melanoma and nevus cells in SLNs. The sensitivities in detecting melanoma cells and nevus cells were $79 \%$ and $54 \%$, respectively (see also Fig. 4). Despite these limited sensitivities, one melanoma-positive and six nevuspositive SLNs would not have been correctly diagnosed if positive RT-PCR results had not induced a careful second microscopic search for cellular correlates of the molecular findings.

\section{Detection of Tyrosinase mRNA in Relation to Morphometric Parameters and S Categories of Melanoma Micrometastases}

The existence of false-negative RT-PCR results in the 33 cases of melanoma micrometastases (without additional nevus cells) suggests the need to study the impact of morphometric parameters as surrogates of tumor burden. One such parameter is the number ( $n$ ) of the SLN slices with (immuno)histologically identified melanoma cells. Table $3 \mathrm{dem}-$ onstrates that the seven false-negative RT-PCR results are confined to those micrometastases that involve not more than two slices. The Spearman correlation is highly significant $(P=.007$, correlation coefficient of 0.464 ).

The second parameter of interest is the distance $d$ of the most centripetally advanced melanoma cells to the interior margin of the SLN capsule. The various $d$ values were classified into the categories between 0.01 and $0.3 \mathrm{~mm}, 0.31$ and $1 \mathrm{~mm}$, and $>1$ $\mathrm{mm}$ and then correlated with the RT-PCR data (Table 4). The $P$ value by Spearman correlation between the $d$ categories and the detectability of tyrosinase mRNA indicates significance $(P=.011$, correlation coefficient of 0.435 ).

The S classification, defined by a combination of $n$ and $d$, correlates with the RT-PCR results at a very
TABLE 4. Contingency among the 33 Melanoma-Positive SLNs without Nevus Cells between Three Categories of Parameter d (Maximum Distance of Melanoma Cells from the Interior Margin of the SLN Capsule) and the Related Tyrosinase RT-PCR Results

\begin{tabular}{lccc}
\hline Tyrosinase RT-PCR & $\begin{array}{c}0.01 \mathrm{~mm} \leq \mathrm{d} \\
\leq 0.3 \mathrm{~mm}\end{array}$ & $\begin{array}{c}0.3 \mathrm{~mm}<\mathrm{d} \\
\leq 1 \mathrm{~mm}\end{array}$ & $\mathrm{~d}>1 \mathrm{~mm}$ \\
\hline Positive & 5 & 9 & 12 \\
Negative & 4 & 3 & 0 \\
\hline
\end{tabular}

Spearman correlation, two-sided: $P=.011$, correlation coefficient 0.435 .

high level of significance $(P=.0004$ by Spearman correlation, correlation coefficient of 0.582 ). The related contingency table is presented as Table 5 and visualized by the last three columns of Fig. 4 .

\section{DISCUSSION}

The SLN is defined as the first extracutaneous target of lymphogenous tumor cell spread and the potential source of subsequent lymph node metastases as well as distant metastases $(1,7,24,25)$. This applies in melanoma as it does in most other solid malignancies. The biological role of regional lymph node metastases for the vitally more relevant distant dissemination has always been an issue of controversial discussion since Virchow's time (2628). Recently, Sleeman (28) denominated lymph node metastases as "bridgeheads" for the evolution of malignant cell clones with the capacity of systemic spread. But even investigators like Cady (27), who denied an active impact of lymph node metastases on survival, explicitly confirmed their prognostic relevance in the sense of an epiphenomenon of systemic metastases.

Regarding malignant melanoma, there is sufficient evidence now for the value of the SLN status as an independent and leading predictor not only for subsequent lymph node metastases in the respective region but also for the patient's outcome and survival $(9,29-33)$. Thus, far-reaching therapeutic consequences like radical completion lymphadenectomy and adjuvant treatment options depend on the SLN evaluation. Micrometastatic involvement and its morphometric classification ( $\mathrm{S}$ classification) have to be considered. Obviously, high quality of the diagnostic tools in respect to specificity and sensitivity is demanded (7).

TABLE 3. Contingency among the 33 Melanoma-Positive SLNs without Nevus Cells between Parameter $n$ (Number of $1 \mathrm{~mm}$ Slices with Histologically Detected Melanoma Cells) and the Related Tyrosinase RT-PCR Results

\begin{tabular}{|c|c|c|c|c|c|c|c|c|c|c|c|}
\hline \multirow{2}{*}{ Tyrosinase RT-PCR } & \multicolumn{11}{|c|}{$\mathrm{n}$} \\
\hline & 1 & 2 & 4 & 5 & 6 & 8 & 9 & 11 & 12 & 13 & 15 \\
\hline Positive & 5 & 5 & 4 & 4 & 2 & 1 & 1 & 1 & 1 & 1 & 1 \\
\hline Negative & 4 & 3 & 0 & 0 & 0 & 0 & 0 & 0 & 0 & 0 & 0 \\
\hline
\end{tabular}

Spearman correlation, two-sided: $P=.007$, correlation coefficient 0.464 . 
TABLE 5. Contingency among the 33 Melanoma-Positive SLNs without Nevus Cells between the Three S Classifications and the Related Tyrosinase RT-PCR Results

\begin{tabular}{lccc}
\hline Tyrosinase RT-PCR & S1 & S2 & S3 \\
\hline Positive & 6 & 8 & 12 \\
Negative & 7 & 0 & 0 \\
\hline
\end{tabular}

Spearman correlation, two-sided: $P=.0004$, correlation coefficient 0.582 .

The highest sensitivity has been reported by various investigators for RT-PCR techniques appropriate to detect melanocyte-specific mRNA fragments like tyrosinase mRNA (10-15, 34-36). Most of these studies were performed using unfixed portions of the SLNs that did not allow a direct correlation with histology in the same sample. Sufficient evidence for an adequate specificity of this approach could therefore not be provided, and percentages of positive RT-PCR results varying between $49 \%$ (13) and $73 \%$ (12) cast further doubts upon its reliability. Therefore, clinical implications for individual patients were usually not derived from the RT-PCR data.

These problems can only be solved by a modified strategy for mRNA analysis using paraffin sections of SLNs. With the presented technique, RNA could be reliably extracted from all paraffin-embedded tissue samples, as shown by the consistently positive detection of $\beta_{2}$-microglobulin mRNA. The expression of tyrosinase mRNA was shown to be closely correlated with the (immuno)histochemical results of the adjacent paraffin sections: RT-PCR for tyrosinase was positive for all SLNs with S2 or S3 metastases of melanoma and was negative in $99 \%$ of the SLNs that lacked microscopically detectable melanoma or nevus cells. Only the SLNs with S1 micrometastases and S0 SLNs with capsulotrabecular nevus cells varied between positive and negative RT-PCR results for tyrosinase mRNA. These findings clearly demonstrate that tyrosinase RT-PCR from paraffin-embedded SLNs is (1) highly specific for melanoma or nevus cells and (2) sufficiently sensitive to detect all S2 and S3 metastases of malignant melanoma, but only a minority of the S1.

Also reduced sensitivity has recently been stated by Palmieri et al. (37) and by Bonin et al. (38) for paraffin-embedded versus fresh SLN tissue. However, neither these investigators, nor others referring to nonparaffin material only, sufficiently considered the presence of tyrosinase mRNA in nodal nevus cells $(10-14,35)$. Some of them even incorrectly presumed melanoma cells to be the only targets of tyrosinase RT-PCR analysis. It has to be emphasized that a positive RT-PCR result is not a definite proof for melanoma metastases in the SLN, but it can be the decisive stimulus that improves the diagnostic accuracy of (immuno)histology, if
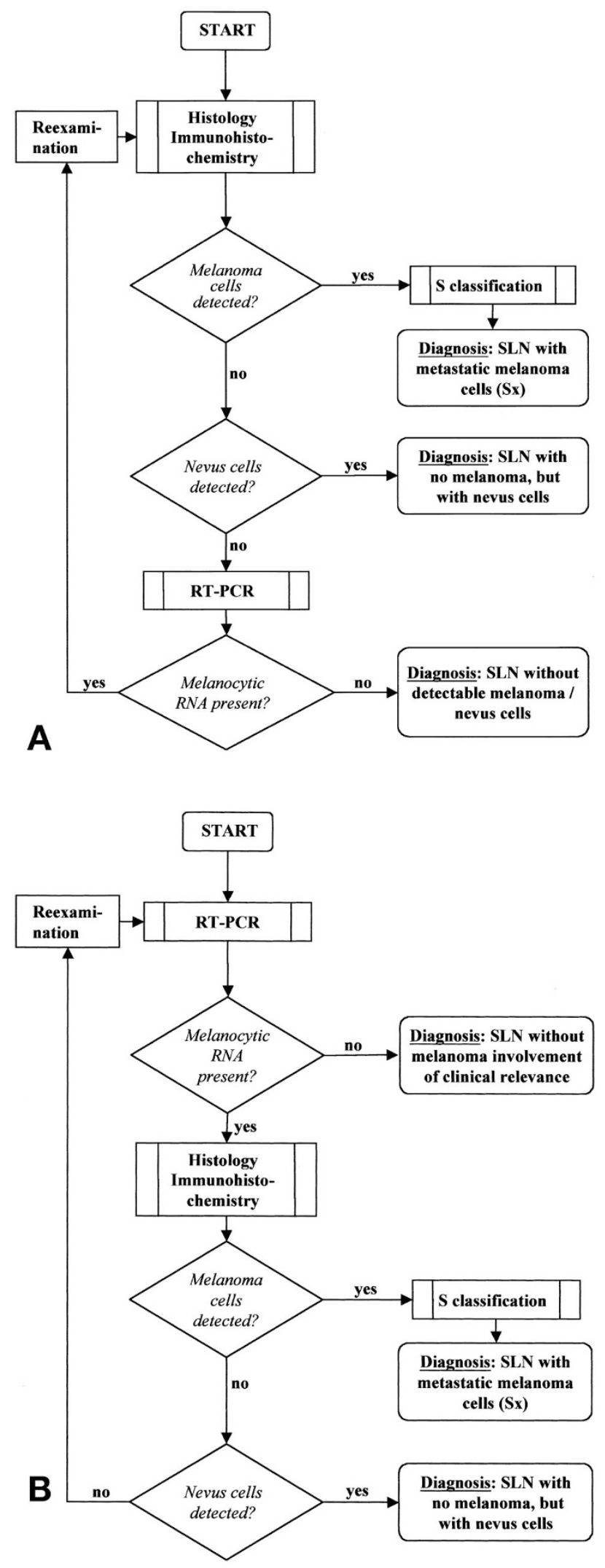

FIGURE 5. Two potential algorithms for the stepwise use of (immuno)histology and RT-PCR techniques in the diagnostic evaluation of melanoma-related SLNs. In Algorithm A, RT-PCR is used as a tool to control histologically negative cases with regard to false-negative diagnoses and to induce their correction by second-look microscopy. In Algorithm B, RT-PCR is performed as a screening operation to guide the whole arsenal of (immuno)histological options to those SLNs that have a reasonable probability to contain clinically relevant metastases. 
paraffin sections adjacent to the source of tyrosinase mRNA are available. In this case, the investigator will find discrete micromorphological correlates with higher probability than in routine situations without the $a$ priori information about the existence of something to be found. In the present study, this fact permitted the additional detection of one melanoma micrometastasis and of six nevus cell aggregates by microscopic reexamination of the same sections where the respective diagnoses had been missed before. This shows that a combined approach of conventional histology, immunohistochemistry, and tyrosinase RT-PCR using adjacent paraffin sections is appropriate to increase the diagnostic sensitivity for both melanoma and nevus cells without loss of specificity. Paraffinbased RT-PCR alone is not superior in sensitivity to high standards of (immuno)histology. The relatively high rate of primarily undetected capsulotrabecular nevus cells by (immuno)histology is due to their frequently low number and dispersed distribution, their inconspicuous cytomorphologic features, and their usually negative reaction with HMB45. It further emphasizes the differential diagnostic relevance of nevus cells in SLNs of melanoma patients, suggesting that current estimations of 3 to $10 \%$ SLNs affected are considerably too low $(16,17)$.

Many investigators now tend to use more than one mRNA target to enhance both sensitivity and specificity of the molecular analysis $(13,15,36-38)$. The future must show whether this strategy brings real diagnostic advantage for the evaluation of paraffin-embedded SLNs too, especially with regard to the distinction between melanoma metastases and benign nevus cell inclusions.

On the other hand, the permanent urge to increase the sensitivity and to detect even single melanoma cells in SLNs may also be overemphasized. So far, melanoma patients with S1 metastases did not show any significant difference in their outcome when compared with patients free of any SLN metastases (S0). This applied both for recurrent disease in the respective lymph node region as well as for distant metastases (9). Although the preliminary median follow-up period (31.5 mo) was relatively short in the original publication, these observations remained valid until now (June 2002, median follow-up of 50.5 mo, referring to the same 342 patients). If these data can be confirmed by multicenter studies with still longer times of followup, the failure of tyrosinase RT-PCR to detect some of the S1 metastases in paraffin-embedded SLNs will become irrelevant for prognosis and further therapy and thus will be tolerable for clinical purposes.

Two different diagnostic strategies visualized by the arrow diagrams of Figure 5 should be consid- ered: first, the currently preferred sequence is characterized by the initial use of histology and immunohistochemistry (Fig. 5A). If melanoma or nevus cells are already discovered under the microscope, then molecular analysis is unnecessary. If, however, the (immuno)histochemical analysis is negative, RT-PCR may help as a control tool against falsenegative diagnoses. In this case, positive RT-PCR results will require the microscopic reexamination of the SLN sections previously investigated, or it will even necessitate the preparation of further sections using additional antibodies like Melan A or NKI-C3 to establish a final diagnosis. Second, this strategy may become interesting in the future when molecular analyses from paraffin material will have sufficiently proven their sensitivity for all SLN metastases with prognostic and/or therapeutic implications (Fig. 5B). Reversing the sequence by initially applying RT-PCR techniques might then minimize the use of expensive immunohistochemical markers. In addition, valuable time of microscopic examination will be saved as it can be restricted to those sections in which metastases or well-defined differential diagnoses (like nevus cells in the case of melanoma patients) must be expected because of positive mRNA findings in the adjacent sections. In analogy to the gamma probe that guides the surgeon to the SLN, RT-PCR assays would serve as detectors of suspect SLNs and of their relevant tissue portions that could then be scrutinized selectively using microscope-related techniques.

The present study tries to continue a successful principle of the sentinel node concept, namely that the diagnostic utility of single analytic or investigative methods can be multiplied if they are interactively connected. Melanoma patients may again be the first to gain benefit from this principle. Furthermore, the close combination of molecular analyses with the (immuno)histological evaluation of paraffin-embedded SLNs should also be promising for patients with other types of malignancies for which SLNE has been shown to represent progress or an additional option for their initial management (39-44).

\section{REFERENCES}

1. Morton DL, Wen DR, Wong JH, Economou JS, Cagle LA, Storm FK, et al. Technical details of intraoperative lymphatic mapping for early stage melanoma. Arch Surg 1992;127:392-9.

2. Alex JC, Krag DN. Gamma-probe guided localization of lymph nodes. Surg Oncol 1993;2:137-43.

3. van der Veen H, Hoekstra OS, Paul MA, Cuesta MA, Meijer S. Gamma probe-guided sentinel node biopsy to select patients with melanoma for lymphadenectomy. Br J Surg 1994; 81:1769-70.

4. Bachter D, Balda BR, Vogt H, Büchels H. "Sentinel” lymphonodectomy with scintillation detector. A new strategy in treatment of malignant melanoma. Hautarzt 1996;47:754-8. 
5. Thompson JF, Niewind P, Uren RF, Bosch CM, HowmanGiles R, Vrouenraets BC. Single-dose isotope injection for both preoperative lymphoscintigraphy and intraoperative sentinel lymph node identification in melanoma patients. Melanoma Res 1997;7:500-6.

6. Starz H, Balda B-R. Sentinel lymphonodectomy and micromorphometric S-staging, a successful new strategy in the management of cutaneous malignancies. Giorn Ital Dermatol Venereol 2000;135:161-9.

7. Cochran AJ, Balda BR, Starz H, Bachter D, Krag DN, Cruse CW, et al. The Augsburg Consensus. Techniques of lymphatic mapping, sentinel lymphadenectomy, and completion lymphadenectomy in cutaneous malignancies. Cancer 2000;89:236-41.

8. Starz H, Bachter D, Balda B-R, et al. Qualitative and quantitative evaluation of sentinel lymph nodes in cutaneous malignancies. Nuklearmediziner 1999;22:253-60.

9. Starz H, Balda BR, Krämer KU, Büchels H, Wang H. A micromorphometry-based concept for routine classification of sentinel lymph node metastases and its clinical relevance for patients with melanoma. Cancer 2001;91: 2110-21.

10. Wang X, Heller R, VanVoorhis N, Cruse CW, Glass F, Fenske $\mathrm{N}$, et al. Detection of submicroscopic lymph node metastases with polymerase chain reaction in patients with malignant melanoma. Ann Surg 1994;220:768-74.

11. Shivers SC, Wang X, Li W, Joseph E, Messina J, Glass LF, et al. Molecular staging of malignant melanoma: correlation with clinical outcome. JAMA 1998;280:1410-5.

12. Bieligk SC, Ghossein R, Bhattacharya S, Coit DG. Detection of tyrosinase mRNA by reverse transcription-polymerase chain reaction in melanoma sentinel nodes. Ann Surg Oncol 1999;6:232-40.

13. Bostick PJ, Morton DL, Turner RR, Huynh KT, Wang HJ, Elashoff R, et al. Prognostic significance of occult metastases detected by sentinel lymphadenectomy and reverse transcriptase-polymerase chain reaction in early-stage melanoma patients. J Clin Oncol 1999;17:3238-44.

14. Blaheta HJ, Ellwanger U, Schittek B, Sotlar K, MacZey E, Breuninger $\mathrm{H}$, et al. Examination of regional lymph nodes by sentinel node biopsy and molecular analysis provides new staging facilities in primary cutaneous melanoma. J Invest Dermatol 2000;114:637-42.

15. Hochberg M, Lotem M, Gimon Z, Shiloni E, Enk CD. Expression of tyrosinase, MIA and MART-1 in sentinel lymph nodes of patients with malignant melanoma. Br J Dermatol 2002; 146:244-9.

16. Carson KF, Wen DR, Li PX, Lana AM, Bailly C, Morton DL, et al. Nodal nevi and cutaneous melanomas. Am J Surg Pathol 1996;20:834-40.

17. Starz H, Balda B-R, Büchels H. Sentinel-Lymphonodektomie bei malignen Melanomen. Eine vorläufige Bilanz aus histomorphologischer Sicht. In: Garbe C, Rassner G, editors. Dermatologie. Leitlinien und Qualitätssicherung für Diagnostik und Therapie. Berlin: Springer; 1998. p. 274-7.

18. Cochran AJ, Starz H. Pathologic aspects. In: Cody HS III, editor. Sentinel lymph node biopsy. London: Martin Dunitz Ltd; 2002. p. 79-90.

19. Bachter D, Balda BR, Vogt H, Büchels H. Primary therapy of malignant melanomas: sentinel lymphadenectomy. Int J Dermatol 1998;37:278-82.

20. Fredricks DN, Relman DA. Paraffin removal from tissue sections for digestion and PCR analysis. Biotechniques 1999;26: 198-200.

21. Stanta G, Schneider C. RNA extracted from paraffinembedded human tissues is amenable to analysis by PCR amplification. Biotechniques 1991;11:304,306,308.

22. Smith B, Selby P, Southgate J, Pittman K, Bradley C, Blair GE. Detection of melanoma cells in peripheral blood by means of reverse transcriptase and polymerase chain reaction. Lancet 1991;338:1227-9.

23. Oda Y, Rose I, Radig K, Wagemann W, Mittler U, Roessner A. Expression of MDR1/p-glycoprotein and multidrug resistance-associated protein in childhood solid tumours. Virchows Arch 1997;430:99-105.

24. Cabañas RM. An approach for the treatment of penile carcinoma. Cancer 1977;39:456-66.

25. Reintgen D, Cruse CW, Wells K, Berman C, Fenske N, Glass $\mathrm{F}$, et al. The orderly progression of melanoma nodal metastases. Ann Surg 1994;220:759-67.

26. Virchow R. Dritte Vorlesung. Allgemeine Physiologie der Geschwülste. In: Virchow R, editor. Die krankhaften Geschwülste. Berlin: Hirschwald; 1863. p. 33-56.

27. Cady B. Lymph node metastases. Indicators, but not governors of survival. Arch Surg 1984;119:1067-72.

28. Sleeman JP. The lymph node as a bridgehead in the metastatic dissemination of tumors. Recent Results Cancer Res 2000;157:55-81.

29. Balch CM, Buzaid AC, Atkins MB, Cascinelli N, Coit DG, Fleming ID, et al. A new American Joint Committee on Cancer staging system for cutaneous melanoma. Cancer 2000;88:1484-91.

30. Cochran AJ. Prediction of outcome for patients with cutaneous melanoma. Pigment Cell Res 1997;10:162-7.

31. Gershenwald JE, Thompson W, Mansfield PF, Lee JE, Colome MI, Tseng $\mathrm{CH}$, et al. Multi-institutional melanoma lymphatic mapping experience: the prognostic value of sentinel lymph node status in 612 stage I or II melanoma patients. J Clin Oncol 1999;17:976-83.

32. Gershenwald JE, Mansfield PF, Lee JE, Ross MI. Role for lymphatic mapping and sentinel lymph node biopsy in patients with thick $(>$ or $=4 \mathrm{~mm})$ primary melanoma. Ann Surg Oncol 2000;7:160-5.

33. Jansen L, Nieweg OE, Peterse JL, Hoefnagel CA, Olmos RA, Kroon BB. Reliability of sentinel lymph node biopsy for staging melanoma. Br J Surg 2000;87:484-9.

34. Lukowsky A, Bellmann B, Ringk A, Winter H, Audring H, Fenske $\mathrm{S}$, et al. Detection of melanoma micrometastases in the sentinel lymph node and in nonsentinel nodes by tyrosinase polymerase chain reaction. J Invest Dermatol 1999;113: 554-9.

35. Van der Velde-Zimmermann D, Roijers JF, BouwensRombouts A, de Weger RA, De Graaf PW, Tilanus MG, et al. Molecular test for the detection of tumor cells in blood and sentinel nodes of melanoma patients. Am J Pathol 1996;149: $759-64$.

36. Li W, Stall A, Shivers SC, Lin J, Haddad F, Messina J, et al. Clinical relevance of molecular staging for melanoma: comparison of RT-PCR and immunohistochemistry staining in sentinel lymph nodes of patients with melanoma. Ann Surg 2000;231:795-803.

37. Palmieri G, Ascierto PA, Cossu A, Mozzillo N, Motti ML, Satriano SM, et al. Detection of occult melanoma cells in paraffin-embedded histologically negative sentinel lymph nodes using a reverse transcriptase polymerase chain reaction assay. J Clin Oncol 2001;19:143743.

38. Bonin S, Niccolini B, Calacione R, Gambardella B, Geatti O, Stanta G, et al. Molecular analyses of sentinel lymph nodes: an open question. J Eur Acad Dermatol Venereol 2002;16: $34-9$.

39. Starz H, Balda BR, Bachter D, Büchels H, Vogt H. Secondary lymph node involvement from primary cutaneous large B-cell lymphoma of the leg: sentinel lymph nodectomy as a new strategy for staging circumscribed cutaneous lymphomas. Cancer 1999;85:199-207. 
40. Düker I, Starz H, Bachter D, Balda BR. Prognostic and therapeutic implications of sentinel lymphonodectomy and S-staging in Merkel cell carcinoma. Dermatology 2001;202: 225-9.

41. Wawroschek F, Vogt $H$, Weckermann $D$, Wagner $T$, Harzmann R. The sentinel lymph node concept in prostate cancer-first results of gamma probe-guided sentinel lymph node identification. Eur Urol 1999;36:595600 .
42. Levenback C. Gynecologic cancers. In: Cody HS III, editor.Sentinel lymph node biopsy. London: Martin Dunitz Ltd; 2002. p. 339-50.

43. Saha S, Bilchik A, Wiese D. Colorectal cancer. In: Cody HS III, editor. Sentinel lymph node biopsy. London: Martin Dunitz Ltd; 2002. p. 351-8.

44. Turner RR. Pathologic aspects. In: Cody HS III, editor. Sentinel lymph node biopsy. London: Martin Dunitz Ltd; 2002. p. 191-208. 